\title{
Idrætten skal på museum - i Viborg
}

\section{Planer om et aktivt idrætsmuseum}

\author{
af Arne Knudsen
}

Idrætten har to hovedepoker i menneskets kulturhistorie i den tid, vi har kendskab til, om end idræt har været en del af menneskets tilværelse også derudover.

Den første epoke i nyere tid er perioden i det gamle Grækenland fra omkring år 800 f.Kr. til omkring år 800 e.Kr. med udløbere til det gamle Romerrige og med en samtidig udvikling i Norden, sådan som helleristninger og bronzeskulpturer beretter det.

De olympiske lege og de første gymnastiksystemer har deres oprindelse i denne periode $\mathrm{i}$ Grækenland og har således to tusinde år bag sig.

Den anden epoke går op til vor tid og er i udstrækning mindre end 200 år. Den har sit udgangspunkt i frihedsrøret i Frankrig sidst i 1700-tallet, og den viser sit første egentlige resultat $i$ den gymnastik, der ser dagens lys $i$ Tyskland og Schweiz med Basedow, Gutts Muths, Jahn og Peztalozzi. En anden udviklingslinie tager form kort tid senere med den engelske sport, hvor boldspil, cricket m.v. udformes.

Imellem disse epoker og som en del af dem er der tendenser, der har idrætskarakter som lege, ridning, dans m.v., tendenser der står svagere i billedet, og som i de fleste tilfælde ikke var for menigmand.

Fælles for de to epoker er, at gymnastikken og idrætten har været en del ofte en betydningsfuld del - af kulturbilledet i de skiftende samfund.

Gennem de seneste år er der vokset frem en stigende interesse for at kende mere til idrætten og dens placering $i$ tidens og samfundets kulturmønster både nu og tidligere. Denne interesse er naturligt nok påvirket af de mange nye muligheder inden for idrætsverdenen, af den øgede forståelse for idrættens væsen og nok også af en genvakt historisk interesse.

Det er i hvert fald en kendsgerning, at også i idrætten er der behov for at kende sin rødder, for at lære af sin fortid.

Overvejelser af denne art ligger bag et initiativ, der nu for snart tre år siden så dagens lys i Viborg, med det sigte at bearbejde mulighederne for at oprette et idrætsmuseum i byen.

Initiativet udmøntedes hurtigt i konkrete arbejdsopgaver med undersøgelser og drøftelser til forskellig side, og resultatet er stiftelsen af den selvejen- 
de institution ,Idrætsmuseet i Viborg", der blev foretaget den 6. december 1984 på et møde på Gymnastikhøjskolen ved Viborg.

Det var den daværende formand for De samvirkende Idrætsklubber, $\mathrm{H}$. Kastrup Andersen, der i 1981 forelagde ideen. Lunten var dermed tændt. I første omgang blev det til mange samtaler med mange spændende visioner, men arbejdet fik først et realistisk forløb, da kredsen bag ideen blev udvidet til også at omfatte repræsentanter for Dansk Idræts Forbund, De Danske Gymnastik- og Ungdomsforeninger, De Danske Skytte-, Gymnastik- og Idrætsforeninger, Dansk Firmà Idræts Union, Viborg Amtskommune og Viborg Kommune.

Repræsentanter for de nævnte institutioner og organisationer har gennem to år dannet den arbejdsgruppe, der gav baggrund for, at ideen fik liv.

Viborg Kommune har fra starten været orienteret om initiativet, og byrådet har set ideen så bæredygtig, at man har ydet et større beløb til det forberedende arbejde.

Så langt, som man indtil videre er kommet, har man følgende pejlemærker som arbejdsopgaver til idrætsmuseet i Viborg:

at registrere, indsamle og opbevare idrætseffekter fra tidligere perioder, så langt tilbage som det er muligt at finde dem.

Udover egentlige idrætsrekvisitter omfatter begrebet ,idrætseffekter“ også film, protokoller, optegnelser, beskrivelser af gamle lege og spil, øvelsesbeskrivelser fra gymnastikken, tegninger af gamle idrætsredskaber m.v.,

at arrangere udstillinger, der giver udtryk for idrættens placering i det kulturmønster, der tegner sig for enhver tidsperiode.

Ved hjælp af billeder, plancher, nye og gamle film m.v. skal disse arrangementer formidle forståelse for det egentlige i de forskellige idrætsaktiviteter,

at foranstalte kurser og andre oplysningsarrangementer for elever $\mathrm{i}$ folkeskolens øverste klasser, efterskole- og højskoleelever m.v., hos hvem der $\mathrm{i}$ disse år spores en voksende interesse for at studere de enkelte idrætsgrene og deres interne problematik, men også et ønske om at se idrætten i relation til det samfundsmønster, den er placeret $i$,

at afholde seminarer for idrættens organisationer, fritidslivets mange organer, kommunalbestyrelsesmedlemmer og andre, der måtte ønske at studere og debattere forholdene omkring idrætten som en del af vort kulturbillede.

Som det fremgår af oversigten over de foreløbige arbejdsopgaver finder initiativtagerne det væsentligt, at et idrætsmuseum ikke blot bliver et opbevaringssted, men at man ved museets bestand af effekter og hjælpemidler $\mathrm{i}$ 
øvrigt vil kunne illustrere de aktiviteter, effekterne har været eller bliver anvendt til, den problematik, der knytter sig til effekternes brug, og de kulturpåvirkninger, der er udgået herfra.

På det stiftende repræsentantskabsmøde for "Idrætsmuseet i Viborg" valgtes en bestyrelse bestående af adjunkt Else Trangbæk, ing. H. Kastrup Andersen, adjunkt Poul Brøndfeld, højskolelærer Hans Kelstrup, museumsinspektør Peter Seeberg og forstander Arne Knudsen til at lede det videre arbejde, foreløbig indtil det ordinære repræsentantskabsmøde i Juni 1985. 
